\title{
A BIG PICTURE PERSPECTIVE OF THE DECOLONIZATION OF PUBLIC ADMINISTRATION DEBATE IN AFRICA: LOOKING BACK AND LOOKING FORWARD
}

\author{
O. I. Nzewi \\ Department of Public Administration \\ University of Fort Hare \\ Bhisho campus, South Africa \\ https://orcid.org/0000-0002-2377-0855
}

\section{T. C. Maramura}

Department of Public Administration and Management

University of the Free State

Bloemfontein, South Africa

https://orcid.org/0000-0002-4419-1887

\section{ABSTRACT}

Trailblazing discussions on "decolonisation" have continuously been building up since Kwame Nkrumah's Pan-Africanist ideological constructs, but not much has been undertaken regarding the rebuilding of the fibre of the Public Administration curriculum. As a result, literature has been embedded in a lot of nuances in decoding the concept of decolonization. Amongst these narratives is the tendency to distinguish the decolonization of the curriculum as a mere African exhilaration which is disguised as a counter-construct to colonization. In light of the adverse effects of colonization on the African curriculum, critical reflections that shoot from a broad review of decolonization approaches in Public Administration are unveiled in this article. The aim is to encourage institutions of higher learning to apply a decolonizing approach that appreciates the pedagogical value of indigenous knowledge relating to Public Administration as a locus and as a focus. The article also covers an exposition revealing how decolonization of the Public Administration curriculum is neither an "anti-West" fad nor a dissuasion to learn from the West and the globalized village. It does this by taking full cognizance of the past without disintegrating the already polarized social fabric. It is against this background that it becomes imperative that South Africa begins to rediscover, and regenerate its local values by enabling the practicalities of decolonizing the curriculum through extending examples in practice. If university repositories and research hubs are going to be reliably contributing to the transformation of the African continent and the global village at length, then it is obvious that the teaching material and how it is delivered will have to certainly change somehow. The article then explores alternatives and sustainable solutions that can be proffered in accelerating the relevance of the alternative indigenous knowledge systems on the Public Administration curriculum.

Keywords: curriculum, decolonization, higher education transformation, indigenization, pedagogy 


\section{INTRODUCTION}

As the popular African proverb goes, "until the story of the hunt is told by the Lion, the tale of the hunt will always glorify the hunter", this article takes a retrospective view of the decolonisation debate in Africa. The aim is to apply a decolonizing approach that appreciates the pedagogical value of indigenous knowledge relating to Public Administration as a locus and as a focus. It traces how the early establishments of higher education institutions in Africa were essentially predisposed to the colonial era. This predisposition allowed not only for the colonisation of the socio-political life of Africans, but also of the educational system of most African nations. Chukwuere notes that the fruits of this colonial history continued to grow, its roots disseminating what "Africanness" (Chukwuere 2017) may be left of the African curriculum. There has been much talk and action aimed at ensuring access to education for all. Global interventions for African educational development, such as the United Nations Millennium Development Goals and the Sustainable Development Goals, have been in motion since the post-colonial era (United Nations 2013). From a general standpoint, this article argues that despite these international interventions aimed at propagating access to education as a basic human right for all, not much has been done to ensure access to an education that has at the core African values and perspectives.

Oelofsen notes that the translation of a curriculum whose core is deeply entrenched in what can be termed an African philosophical world view goes beyond the endless confrontations between the superiority and inferiority debates surrounding Africa and its former colonial powers (Oelofsen 2015). This article posits that firstly, the decolonization of the curriculum in Public Administration is more about actualizing teaching and learning through the enabling of curriculum reform approaches that prioritise enduring African values and history without negating African experiences. Secondly, the article also puts research at the front and centre of the decolonization wave in terms of how its most enduring principles inform and impact African-centred research for the African intellectual and the global citizens at large.

This study thus explores how institutions of higher learning can actualize the application of curriculum decolonization in Public Administration within the frames set for the article. In the quest to gain deeper insight, through an introspective and retrospective analysis of the possibilities of actually decolonizing the curriculum, an extensive review of the literature is done.

\section{CONTEXTUAL BACKGROUND OF DECOLONIZATION: A PAN-AFRICAN DISCOURSE}

Much like Pan Africanism, the decolonisation debate can be described as a "rebel" philosophy 
of Africa rising. Indeed, no other African inspired movement or paradigm matches decolonisation in description as Pan Africanism. This article thus contextualises the decolonisation debate within the Pan Africanism discourse. Pan Africanism was a response to colonialism, which necessitated the loss of economic, cultural and political liberation. Wa Thiong'o maintains that the Berlin Conference of 1884 only worsened the situation by disjointing Africa into "British, French, Portuguese, German, Belgian, and Spanish Africa" (Wa Thiong'o 2009, 9). Pan-Africanism was brought forward as a tangent to reunite Africa, towards what Kwame Nkrumah termed the United States of Africa or what Mazrui termed the "continental-union government" (Mazrui 1978). More so, Pan Africanism has been defined as a philosophy that has been pursued to uphold the model of a united Africa (Le Grange 2018).

Although marred by some challenges, the Pan African philosophy evolved without compromising its main goal of African unity (Geiss 1967; Lebeloane 2017; Nzewi 2008). Actually, Azikiwe argues that Pan Africanism was instrumental because it epitomized a discourse that made a concerted effort towards logically unifying Africa and enabling the delinking from the colonial regime (Azikiwe 1970). Pan Africanism has been criticised as an "elitist" endeavour lacking proper grassroot credibility (Guattari 2001). However, it can be argued that Pan-Africanism has been instrumental in enabling the economic, political and cultural freedom of the Africans (Walker 1991, 86). This simply implies that the process of curriculum decolonization has to be about "unlearning, deconstructing and dismantling of the cultural violence of dehumanization as a culmination of the systemic oppression of the colonization" (Jansen 2017). In other words, it has to be African people centred.

\section{THE TRADITIONALISTS/ THE RADICALS/THE INNOVATORS: THEORISING DECOLONIZATION}

Bell and Tabensky assert that humans understand things in a particular way, which implies that social reality is constructed by the models that humans perceive as dominant (Bell 2002; Tabensky 2008). Understanding this brings us to the classification of the decolonization debate along three prisms or views: the traditionalists, the radicals and the innovators. These are discussed below.

\section{Traditionalists}

The traditionalists, such as such as Diop and Fanon, only pushed for the need to change the lenses through which the curriculum was viewed, from the colonizer's point, and this led to the genesis of the radicals (Diop 1974; Fanon 2008). For Fanon, from a traditionalist perspective, the very process of decolonizing the world is what gave birth to a new person and to the new 
mode of being a human, independent of the colonizer's influence (Fanon 2008). However, this study affirms that traditionalists appeared to have a limited view of what decolonization fully entailed in the eyes of the colonized. Thus, classifying the traditional approaches to the debate begins from the early decolonization debates, which can be traced back to the figure of Fanon and other figures like Said, Ahmed, and Spivak (Said 1988; Ahmed 1996; Spivak 1999). The traditionalists simply argued on how the present day curriculum is moulded through the lenses of the colonizer and how efforts were supposed to be made in reflecting on the post-colonial era in the present-day curriculum (Azikiwe 1970).

\section{Radicals}

The model of the radicals is informed by advocating for the adoption of African studies at the institutions of higher learning in promoting a thought process that is detached from the Western influence (Mangcu 2016). Likewise, the radicals are informed by the normative, that there is a supposed resistance to change by the colonizer in the post-colonial era, and they argue for placing more emphasis on the African language as a medium of instruction, in the plight for decolonizing the curriculum (Pilane 2016). Furthermore, within the decolonization of the curriculum debate, Wa Thiong'o's ideal of decolonization is one of the most radical epitomes (Wa Thiong'o 2009). Therefore, this study deems it suitable to comprehend the debates of Wa Thiong'o as an African theorist of decolonization at the level of other radical thinkers like Nabudere, Pilane, Chetty and Knaus (Nabudere 2011; Pilane 2016; Chetty and Knaus 2016). Thus, the radicals supported the deconstruction of the institutions by maintaining the reduction of the pedagogical isolation, hierarchical structure and subject focus, and creating what they termed the "Pluriversity" as well as denouncing the "University" (Mangcu 2016).

\section{Innovators}

The innovators seek to find if there are any possible alternative approaches to decolonization that move away from the generally accepted traditional and radical approaches. Innovators like Heleta, Muchie, Le Grange and Jansen proffer that there should be much more emphasis placed on the African language, which supports the facilitation of communication and understanding of the curricula, instead of just striking off the English language simply because it is the language of the colonizer (Heleta 2016; Muchie 2003; Le Grange 2018; Jansen 2017). The innovators further embrace inclusivity, by accepting that global discourses of decolonization can be advanced within a framework that conjoins pan-Africanism, ideologies of alterity, multiculturalism as well as views on the processes of contemporary globalization (Muchie 2003). 


\section{DECOLONISATION OF THE CURRICULUM AS A CONCEPT}

The unsurprising factor is that decolonization is not even new in literature. It can be traced back to the supposed father of Pan-Africanism W. E. B. du Bois. This is further highlighted in the discussion below. Hansen argues that the unforeseen fact is that despite all the literature that has incessantly been churned out by various scholars on decolonization, from Derrida to Said, Spivak, and Bhabha, the problem underlying curriculum decolonization remains an unsolved puzzle within Public Administration in South Africa (Hansen 1977). This is because decolonization of the curriculum in South Africa presently has been more aligned to moving trends, which come and fade away as opposed to the core of what this article deems as decolonization of the curriculum and where it stems from (Le Grange 2018). For instance, decolonization of the curriculum has been strongly aligned to \#Fees must Fall, \#Rhodes must fall and \#Afrikaans must fall protests (Pilane 2016). However, these are just fads, which we argue argue are movements mechanically hijacked by a few members with egotistical fiats. It is also interesting that while these movements stem from grassroots grievances about the status quo, the "intellectual" hacks seem to prefer to "surf" the wave of these protests rather than seek more deeply entrenched African value systems upon which to build the debate.

\section{Practical decolonisation}

This article argues that \#Fees must Fall, \#Rhodes must fall and \#Afrikaans must fall protests are simply fads and not the core of curriculum decolonization because, what then happens when Rhodes Falls? How is that practical decolonization? Or are we looking for wholly "symbolic" gestures of simply removing statues and renaming names and buildings. For the Afrikaans must fall protest, if we argue for a rainbow nation in South Africa, what happens then if the Afrikaans language falls? Is that a credible starting point or culmination of the decolonization debate? We argue that practical decolonisation certainly goes way beyond that. Obviously not to discredit the emotional and psychological trauma that was and is still being borne from the historical legacy of apartheid, in which non-white students are exposed and caught up in the Afrikaans misdemeanour both during and after apartheid. Our idea of practical decolonisation of the curriculum is that it must be a deliberate, intentional and rational process. We argue that as much as it involves erasing any possible reminders of the colonial era, surfing the wave of anticolonial or apartheid protests fails to intentionally and rationally establish the intellectual and institutional design parameters for an African inspired curriculum, which is critical for building lasting institutions (Nzewi 2011). This is because, much like any institution, a practical decolonised curriculum, while embracing symbolic action, must emphasise values and embody 
some centrality of meaning (March and Olsen 1989). Ascribing rationality as an attribute to practical decolonisation of the curriculum stems from the rational choice theory, which, while not absolving actors from personal experiences of history as foundations of intent, involves strategic calculation based on expectations of how likely others within the decision making space will behave (Hall and Taylor 1996). To this end, intent, calculation and rationality must be important antecedents of the practical decolonisation which we propose.

\section{Decolonisation as constructivist}

Le Grange argues that decolonization should be inclusive of the university because it is impossible to decolonize the curriculum without decolonizing the university (Le Grange 2018). However, in grand theorising of the decolonisation discourse, we argue that a practical, decolonised curriculum design that is intentionally entrenched to deal with the practical implications of such curriculum transformation will tend to have consequences outside its intended realm. This outlook can be inferred from Cesair and Wa Thiong'o's definitions of decolonisation. For Césaire, "decolonization is about the consciousness and rejection of values, norms, customs and worldviews imposed by the former colonizers" (Césaire 2000). Wa Thiong'o also proceeds to confirm that decolonization of the curriculum is about Africans engaging in a longsighted session with themselves in what he terms "a quest for relevance" (Wa Thiong'o 1998). Consequentially, this does not mean that decolonization of the curriculum will isolate the African curriculum from the rest of the globalized world. It only means enabling the African history to be informed through an African lens; hence Wa Thiong'o notes that decolonization is about the "unlearning, deconstructing of dehumanization as a culmination of the systemic oppression of the colonization" (Wa Thiong'o 1998).

Given this exposition, it becomes quite clear that there are so many dimensions to the essence of decolonization. The above definitions reflect our central arguments in conceptualising decolonisation of the curriculum. To these, we add that decolonisation of the curriculum is an intentional, strategic and rational approach to curriculum development. Muchie affirms that the concept of curriculum decolonization enables a significant review of the systematic transformation of the old hegemonic normative to paradigmatic shift that is inclusive of the African indigenous knowledge systems (Muchie 2003).

\section{DECOLONISING CURRICULUM IN PUBLIC ADMINISTATION}

More than two decades into post-independence South Africa, it is unmistakable how Western values are still regarded as the yardstick for superiority or superior education, in a postapartheid era (Molefe 2016). As a teaser, we open this section of our discussion by reflecting 
on how the "Father of Public Administration", Woodrow Wilson, who happened to be the $28^{\text {th }}$ president of the United States of America, was born to a slave-owning family (Nzewi 2011). Although this is not the avenue to discuss the proclivities of Woodrow Wilson's heritage or the use of this as a benchmark to assess Wilson's deservedness of such a title, it begs some reflection. That Woodrow Wilson's 1800s public administration/politics dichotomy is embedded as a paradigm taught as part of the $21^{\text {st }}$ Public Administration curriculum in the decolonisation debate era in South Africa suggests either a dearth of or a disregard of a more historically relevant paradigm for South African Public Administration. In our view, this historically relevant paradigm must not be confused with the apartheid era Public Administration scholars in South Africa, whose treatise significantly impact the present curriculum. For instance, apportioning the "father of South African Public Administration" status to J. J. N. Cloete and his six generic principles of South African Public Administration raises the same questions. Our conceptual determination of the decolonisation of the curriculum highlights a rejection of a worldview that precludes the personal experience of history. While there are articles that engage the dichotomy of practice and experience in Public Administration in apartheid South Africa, there has been little effort to craft a curriculum that reflects Wa Thiong'o's missing historical "quest for relevance" (Chipkin and Lipietz 2012). This is because there is lack of deliberate and intentional strategic positioning of curriculum recrafting which comes from a reckoning with South African history, values and grassroots philosophy in Public Administration.

As a result, what we have is a Public Administration curriculum that has not successfully dismantled the basic tenets of the discipline from a decolonisation view point. Therefore, there is no philosophically and African value based response to the constitution of Public Administration as a discipline. What we have so far is, in essence, a mere surfing of the decolonisation wave. In the subsequent sections we suggest possible avenues of achieving this.

\section{ACKNOWLEDGING THE INDIGENOUS KNOWLEDGE SYSTEMS}

Indigenous knowledge is developed around the specific condition of people in a particular geographical area, and as a result, it becomes unique and locally informed. Additionally, indigenous knowledge is based on personal and historical experiences that have been established over time and which are continuously developed with every incoming experience (Agathangelou 2016). The colonial era ushered in the establishment of knowledge which was informed by the historical experiences of the dominant Western powers. In decolonizing the curriculum, IKS seek to challenge the knowledge generation processes, which have been dominated by the West. IKS further seek to advance the consideration of existential boundaries 
between epistemology and democracy. Malisa and Nhengeze confirm that IKS have been influential in enabling the transformation of the scientific discourse and piloting the productive engagement of how knowledge systems can be sustainable in a post-colonial era (Malisa and Nhengeze 2018).

Colonialists deconstructed and decentred the African chiefdoms, kingdoms, cultural institutions, economies and knowledge hubs. This deconstruction involved formalizing the creation of a knowledge hub which propagated the idea that "Africans will always lack history, strong economies, democracy and intelligence" (Hansen 1977). This study argues that the essence of IKS, which represent an important ingredient of curriculum deconstruction, represents the idea that a domestic culture should be protected and developed in enabling a decolonized Africa. This would require the formation and embracing of alternative knowledge systems whose accuracy stems from the historical evolution of the oppressed instead of the oppressor. Mazrui and Tamburro espouse that this formation should essentially emanate from the idea that the renaissance of African IKS, which argues that African knowledge systems have been persistent, yet, largely ignored in modern knowledge circles (Mazrui 1978; Tamburro 2013).

Infusing IKS will be instrumental in the decolonization of the curriculum, providing alternative frameworks for knowledge, which delinks from the Western ideal of knowledge. For instance, Nzewi in Musical sense and meaning: an indigenous African perspective, exhibits the enduring legacy of skills and knowledge transfer in African knowledge systems (Nzewi 2011). The book is "co-authored" by African Igbo traditional master mother musicians in the Eastern part of Nigeria. In exhibiting the systematic, formal and compositional principles of the tuned drum row music types, the mother musicians, show the explicit theory and systematic knowledge transfer possibilities evident and needed in African IKS. In this case, the knowledge base exists, albeit, in need of acknowledgement, intellectual protection, funding and knowledge transfer infrastructure. The question, then, is, can this be mirrored in Public Administration?

We argue that it can. To be sure, there has to be a strategic refocusing of the Public Administration curriculum, beginning with the intellectual protection of existing culturally relevant history and practice of governing that is uniquely local. Additionally, the knowledge transfer infrastructure must be in place through the provision of knowledge strands and governance contexts embedded in indigenous knowledge.

\section{AN AFRICAN CURRICULUM?}

In changing the narrative of the African curriculum in the $21^{\text {st }}$ century, encouraging institutions of higher learning to apply a decolonizing approach which appreciates the pedagogical value 
of indigenous knowledge in Public Administration is critical. This goes on to confirm the essentials of education within the continuum of indigenous knowledge as a transformational tool which projects towards alternative educational principles. In a post-1994 South Africa, reimagining and rethinking of a decolonized Public Administration curriculum activates curriculum reform approaches, initiatives and outcomes that are pro-African. Zeleza submits that activating curriculum reform approaches essentially begins by instituting the "centrality of Africa" within the curriculum, such that outcomes are deeply grounded within African model and praxes (Zeleza 2009).

It will be disingenuous to this debate to ignore that there is obviously a bag of complexities involved in decolonizing the curriculum. While there are movements across Africa in using IKS as a curriculum reform catalyst, much of these initiatives are fragmented. While these movements are commendable, in terms of preserving the knowledge data base and protecting intellectual property rights there seems to be little attention paid to the issues of knowledge transfer (teaching) and curriculum development. It is either that this component of the curriculum is not understood or is treated as an extra curricula activity or there seems to be a dearth of skilled professionals to transfer this knowledge.

Phiri notes some of the challenges in terms of curriculum on IK, such as; very limited clarity on the requirements of the curriculum, limited scope in terms of content of the curriculum, poor communication and lack of literature or resources to supplement teachers' guides (Phiri 2008). Thus, while it is laudable that there is provision of IK components to education, it is important not to compromise the issue of knowledge transfer. These complexities are already compounded by the factors involving the current curriculum that propagates a misinterpretation of African governments because the narratives have already been modelled by how the colonizer wants the rest of the world and the African to view Africa (Du Preez 2018).

This article asserts that these kinds of misconceptions about Africa are what causes the continued alienation of Africa; hence, it is critical that the Public Administration curriculum be innovatively reformed. This can be actualized by reconsidering how the study and practice can be organized. However, in ensuring curriculum reformation, a decolonized curriculum should not disregard the global context in which Africa operates and co-exists with other continents (Department of Education 2008). Narrative change for curriculum reformation will actually be enabled by direct participation in the knowledge generation and determination so that indigenous knowledge systems can become foundational for research and innovation processes in Public Administration. According to Le Grange, the African renaissance of indigenous knowledge production systems proffers that in ensuring the innovative approach to the 
decolonization of the curriculum, the interrogations below have to be made towards understanding:

1. What are the regulations governing the definition of knowledge within the Public Administration continuum?

2. What type of knowledge is being generated in the institutions of Higher learning?

3. What type of research questions are being asked? Do they move Africa forward or backward?

4. How does the accreditation of the knowledge being produced in institutions of higher learning enable Africa? (Le Grange 2016).

For us in this article, we add to these questions by providing the following identifiers, which are based on our conceptualisation and contextualisation of decolonisation in the South African Public Administration curriculum:

1. What will a strategic engagement with decolonisation entail?

2. What are the rational and intentional identifiers for an innovative and dynamic decolonisation process?

3. How do we begin to build the knowledge transfer infrastructure in the relationship between IKS and the present modern knowledge systems?

4. What will constitute the philosophical underpinnings of such curriculum transformation?

\section{CONCLUSION}

In the decolonisation debate, it is essential to reinforce that although different theorists have articulated their views on decolonizing of the curriculum, their different perspectives appear to centralize the concept as the need to hoist African indigenous knowledge systems by enabling the younger generations to embrace the "Africannised" system. Additionally, the decolonization debate should neither be treated simply as an anti-West fad nor a dissuasion to learn from the West and the globalized village. Rather, it should be a process of engaging curriculum architects to streamline the Public Administration curriculum to mirror on the philosophy and epitomes of the African society, because knowledge does establish influence by subliminally supporting the truth through the perspective from which it is made.

\section{REFERENCES}

Agathangelou, Anna. 2016. "Fanon on Decolonization and Revolution: Bodies and Dialectics". 
Globalizations 13(1): 110-128.

Ahmed, Aijaz. 1996. Jameson's Rhetoric of Otherness and the National Allegory, ed. Bill Ashcroft et al. The Postcolonial Studies Reader, London and New York: Routledge.

Azikiwe, Nnamdi. 1970. My Odyssey. New York: Praeger.

Bell, Richard. 2002. Understanding African philosophy. Routledge.

Césaire, Aime. 2000. Discourse on colonialism. Monthly Review Press, New York.

Chetty, Rajendra and Christopher Knaus. 2016. "Why South Africa's universities are in the grip of a class struggle." Sunday Times 13 Juanuary 2016. http://www.timeslive.co.za/ sundaytimes/opinion/2016/01/13. (Accessed January 2019).

Chipkin, Ivor and Barbara Lipietz. 2012. Transforming South Africa's racial bureaucracy: New Public Management and public sector reform in contemporary South Africa. Public Affairs Research Institute. London: Palgrave Macmillan.

Chukwuere, Joshua. 2017. "From decolonisation to digitalisation of education in South Africa" International Journal of Sciences and Research 73: 2-11.

Department of Education. 2008. Report of the ministerial committee on transformation and social cohesion and the elimination of discrimination in public higher education institutions. Final Report, Department of Education, Pretoria.

Diop, Cheikh. 1974. The African Origins of Civilization: Myth or Reality? Translated by M. Cook. Westport, Conn: Lawrence Hill.

Du Preez, Petro. 2018. "On decolonization and internationalization of university curricula: What can we learn from Rosi Braidotti?” Journal of Education 74: 56-69.

Fanon, Frantz. 2008. Black skin, white masks. New York: Grove Press.

Geiss, Imanuel. 1967. "Notes on the development of Pan Africanism." Journal of the Historical Society of Nigeria 3: 719-740.

Guattari, Felix. 2001. The three ecologies. Translated by Ian Pindar and Paul Sutton. London: The Athlone Press.

Hall, Peter and Rosemary Taylor. 1966. "Political Science and the three new institutionalisms." Political Studies 44(5): 936-957.

Hansen, Emmanuel. 1977. Frantz Fanon: Social and political thought. Columbus, OH: The Ohio State University Press.

Heleta, Savo. 2016. "Decolonisation of higher education: Dismantling epistemic violence and Eurocentrism in South Africa." Transformation in Higher Education 1(1): 123-130.

Jansen, Jonathan. 2017. As by fire: The end of the South African university. Cape Town, RSA: Tafelberg.

Le Grange, Lesley. 2016. "Decolonising the University Curriculum.” South African Journal of Higher Education 30(2): 1-12.

Le Grange, Lesley. 2018. "Spinoza, deep ecology and education informed by a (post) human sensibility." Education Philosophy and Theory 50(9): 878-887.

Lebeloane, Lazarus. 2017. "Decolonizing the school curriculum for equity and social justice in South Africa." Bulletin for Christian Scholarship 82(3): 111-128.

Malisa, Mark and Philippa Nhengeze. 2018. "Pan-Africanism: A Quest for Liberation and the Pursuit of a United Africa." Genealogy (2)28: 1250-1270.

Mangcu, Xolela. 2016. "Decolonizing South African sociology: Building on a shared text of blackness". Hutchins Center for African and African American Research 13(1): 45-59.

March, James and Olsen, Johan. 1989. Rediscovering institutions: The organisational basis of politics. New York: The Free Press.

Mazrui, Ali. 1978. Political Values and the Educated Class in Africa. Berkeley, CA: University of California Press, 1978. 
Molefe, Thato. 2016. “Oppression must fall: South Africa's revolution in theory.” World Policy Journal 33(1): 32 .

Muchie, Mammo. 2003. The Making of the Africa-Nation: Pan-Africanism and the African Renaissance. London: Adonis \& Abbey Publishers Ltd, 2003.

Nabudere, Dani. 2011. Africology, philosophy, and wholeness: An epistemology. Pretoria: Africa Institute of South Africa.

Nzewi, Ogochukwu. 2011. "Africa's regional integration: A reflection on grand theory". Journal of Public Administration 46(Special issue 1): 893-907.

Nzewi, Ogochukwu. 2008. The Role of the Pan African Parliament in African Regionalism (20042006): An Institutional Perspective. University of Pretoria, South Africa.

Oelofsen, Rianna. 2015. "Decolonisation of the African Mind and Intellectual Landscape". African Lineage 16(2):130-146.

Phiri, Absalom. 2008. "Exploring the Integration of Indigenous Science in the Primary School Science Curriculum in Malawi." PhD Dissertation, Virginia Polytechnic Institute and State University.

Pilane, Pontsho. 2016. "Three reasons why \#FeesMustFall protests will continue" http://mg.co.za/ article/2016-01-13-three-reasons-why-feesmustfall-protests-will-continue. (Accessed on 28 January 2019).

Said, Edward. 1988. Crisis (in Orientalism) in Modern Criticism and Theory. Essex: Longman.

Spivak, Gayatri. 1999. A Critique of Postcolonial Reason. Cambridge: Harvard University Press.

Tabensky, Pedro. 2008. "Post-colonial heart of African philosophy." South African Journal of Philosophy 27(4).

Tamburro, Andrea. 2013. "Including decolonization in social work education and practice." Journal of Indigenous Social Development 2(1): 1-16.

United Nations. 2013. The Millennium Development Goals Report. Washington DC: United Nations.

Wa Thiong'o, Ngugi. 2009. Decolonizing the Mind. The Politics of Language in African Literature. Nairobi: East African Educational Publishers Ltd.

Walker, Clarence. 1991. Deromanticizing Black History: Critical Essays and Re-Appraisals. Knoxville: University of Tennessee Press.

Zeleza, Paul. 2009. "African studies and universities since independence: The challenges of epistemic and institutional decolonization." Transition 101: 110-135. 